\title{
In memoriam Colin Ernest Ridsdale (18 January 1944 - 5 January 2017)
}

\author{
P. Baas ${ }^{1, *}$, J.T. Pereira ${ }^{2}$, K.M. Wong ${ }^{3}$, P.H. Hovenkamp ${ }^{1}$,
} P.J.A. Keßler ${ }^{4}$, D.M. Newbery ${ }^{5}$

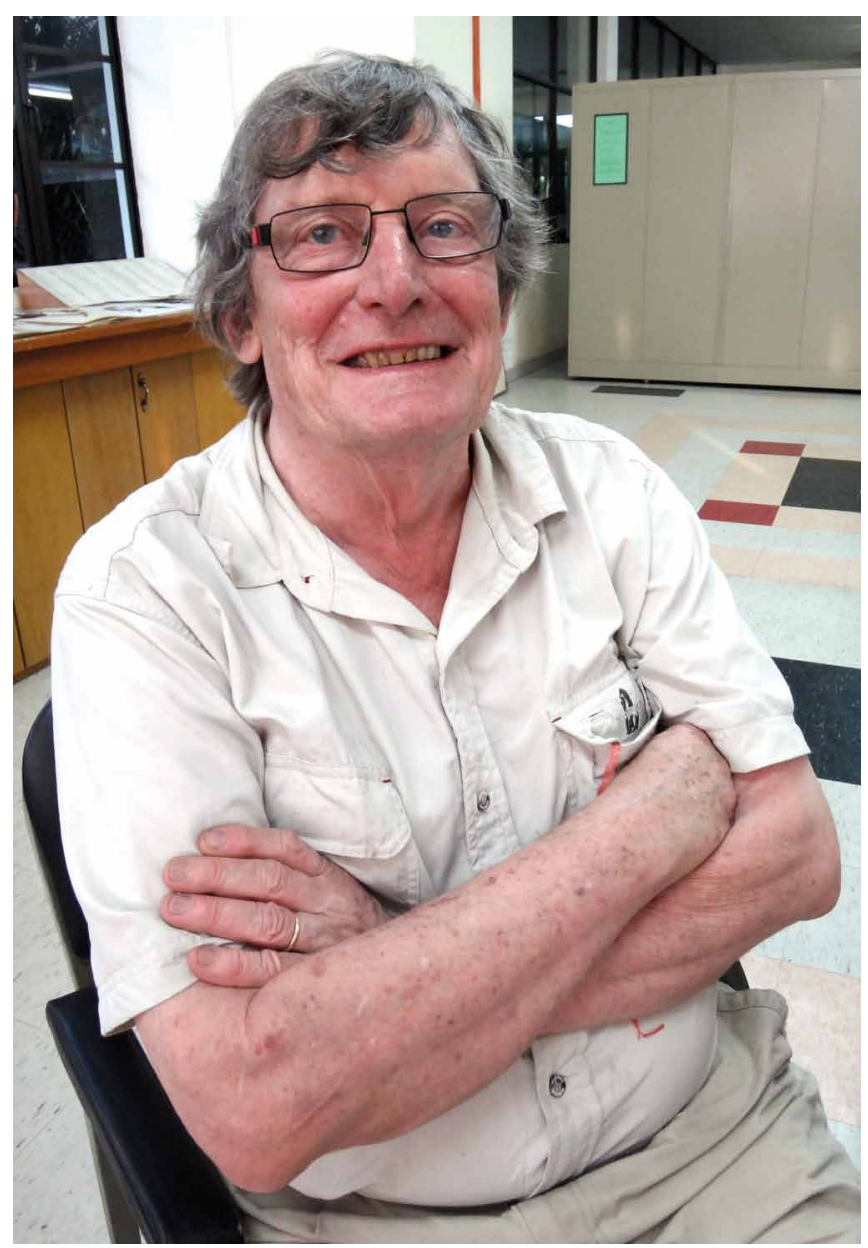

Colin Ridsdale in the Sandakan Herbarium - 2015. Photo by K.M. Wong.

\footnotetext{
${ }^{1}$ Naturalis Biodiversity Center, section Botany, P.O. Box 9517, 2300 RA Leiden, The Netherlands;

corresponding author e-mail: pieter.baas@naturalis.nl

${ }^{2}$ Forest Research Centre, Peti Surat 1407, 90715 Sandakan, Sabah, Malaysia.

${ }^{3}$ Singapore Botanic Gardens, 1 Cluny Road, Singapore 259569.

${ }^{4}$ Leiden University, Hortus botanicus, 5e Binnenvestgracht 8, $2311 \mathrm{VH}$ Leiden, The Netherlands.

${ }^{5}$ University of Bern, Institute of Plant Sciences, Tropical Foreast Ecology, Altenbergrain 21, 3013 Bern, Switzerland.
}

Following a short illness Colin Ridsdale passed away on 5 January 2017, just two weeks short of his 73rd birthday. Colin was a consummate botanist, who throughout his checkered career was fascinated by plants, their taxonomy, ecology, uses, and horticultural potential

Born in Bristol, he attended Weston-Super-Mare Grammar School where he was in charge of the school gardens and served on the local horticultural society. His academic training in botany was at the University of Bristol, where he ultimately defended his $\mathrm{PhD}$ thesis on a revision of the genus Uncaria of the Rubiaceae. That species-rich family would hold his active interest throughout his life. Prior to his $\mathrm{PhD}$ he had served from 1966 to 1968 on the staff of the Department of Botany, Lae, Papua New Guinea, laying the foundation for his later expertise and experience as a tropical field botanist. From PNG there were excursions to the Philippines, Indonesia, and Singapore. In 1971 he was selected in Leiden for one of the two first grants from the Foundation for the Advancement of Malesian Botany, funded by B.A. Krukoff, initially to revise Leeaceae for Flora Malesiana, later to monograph the far more speciose Naucleeae (Rubiaceae). Leiden would become his home base for later botanical pursuits. In Holland he met his wife Marjolein Hiltermann and here he raised their two sons Robin and Lennard. Since no vacancy was available at the then Rijksherbarium, Colin remained a Krukoff Botanist until the modest funds had completely dried up. However, as an Honorary Staff member in Leiden he was successful in continuing his work on a great number of projects and contracts that demanded his unique expertise.

In 1984, he joined the Palawan Botanical Expedition of the Swedish Hilleshög Forestry Company and the Ministry of Natural Resources of the Philippines. This resulted in invaluable new information on rare plants and endemics of the varied but botanically little-explored landscapes of Palawan.

In 1989 Colin joined the Danum Valley project, four years after the Stirling-Bern main dynamics plots had been set up, and continued his input right up until 2016. He took on the considerable task of confirming or revising the identifications of the c. 18 thousand trees of the first census, and then identifying recruits (into the $10-\mathrm{cm}$ dbh class) enumerated in the following ones of 1996, 2001, 2007 and 2015 (on average c. 1.5 thousand trees each). A large majority of the trees, especially those of the understorey, were infertile. This required extensive collection, storage, cross-checking, revising, and sometimes renaming, thousands of vegetative specimens. The updating of list after list was a formidable task. Over the years, whenever fertile material became available, many taxa could be more confidently named. Gradually, the taxonomic status of the 
plots rose to over $98.5 \%$ trees named to species level. From 1995 , the set of smaller satellite plots at Danum needed similar attention. Without this high-level and consistent contribution, supported by the Leiden and Sandakan Herbaria and colleagues at both institutions, the ecological results and subsequently published findings would not have been possible. Combining the skills of a good generalist tropical botanist with a specialist interest in a species-rich family (Rubiaceae) is very unusual, and in this Colin excelled. It was greatly to the benefit of the Danum Programme to have had him associated with it for so many years. The important long-term (30-yr) forest dynamics research achieved at Danum has, without doubt, depended on it being studied in one the world's best-identified set of plots. The Sandakan Herbarium also benefited tremendously from Colin's visits where he not only identified Danum Valley plants but also materials of Rubiaceae and other families collected elsewhere. During his last visit, he was especially concerned about the well-being of the Herbarium and provided valuable inputs on ways to solve problems in managing the Herbarium and its specimens. He also shared his views on the future of the Herbarium and provided ideas on how to move forward in botanical research. Colin enjoyed the company of like-minded field staff and appreciated the broad knowledge of forestry staff, particularly the late Leopold Madani and Postar Miun, who had accompanied him on his trips to Danum Valley.

In 1990 Colin served as a consultant in the Barito Ulu Project, Indonesia; in 1991 as expert botanist in the field training programme at Isabela State University, Luzon, the Philippines; from 1991-1995 as consultant/collaborator in the Flora of Ceylon project coordinated by the Royal Botanic Gardens, Kew; in 1993-1994 as Mercer Scholar at the Arnold Arboretum of Harvard University for the study of Rubiaceae; in 1995 as advisor for the Manila Zoo and Botanical Garden; in 1995-1996 as senior researcher to coordinate ecological and ethnobotanical research in the Vogelkop in the multidisciplinary ISIR programme (Irian Jaya Studies); in 1996 as consultant for the Cat Ba National Park in Vietnam. From 2005-2006 he was a senior researcher for the EU project Open Source for Weed Assessment in lowland paddy fields in Laos and Cambodia where the collection, identification, and description of these taxa were used to create interactive keys. From 2006-2008 he was involved in the EU Project BIOTIK, creating a first network of South Asian and European partners interested in applied computer science for taxonomy and the construction of interactive keys to the trees of two hotspots of biodiversity: The Western Ghats and the Annamite Mountain range of Laos PDR. Most recently, in 2016, Colin looked forward to work on a treatment of the Rubiaceae for the Flora of Singapore. It was during his visit to the Singapore Herbarium last November that the symptoms of the cancer, which turned out to be fatal, became apparent.

The above review of substantial projects and contracts is incomplete, but it is important to emphasize that most of them also involved extensive fieldwork and plant collecting. Colin's herbarium collections in L, from the tropical rain forests of New Guinea, India (Kerala), the Philippines, Borneo, Laos, and Sri Lanka number close to seven thousand and include numerous new species and records. He had a very keen eye for rare and interesting plants, not only in the taxa of his own specialization but as a true floristic generalist.
Colin was particularly generous to younger botanists and gave much effort in pre-sorting and recommending herbarium specimen loans for various studies, and where pertinent also contributed his own insights that were often instructive. He also provided them with valuable literature, that was not available to them.

As a keen gardener he often volunteered to work in the gardens of relatives and friends and to enrich their assortment of plants with cuttings and seeds from his own gardens or other sources. In later years, he spent much of his spare time in assembling information and illustrations on useful plants and fruits and ethnobotany. The resulting database was still a work in progress at the time of his untimely death. In 2005 he wrote a very nice popular book called Trees (together with John White and Carol Usher) in the Eyewitness Companions series.

Colin had a great sense of humour. When informed that the Sandakan Herbarium, to which he was a very welcome visitor, had framed a portrait of him and added it to their portrait gallery of Bornean botanists placed along the upper corridor, he wrote that he felt honoured he had been "framed and hung". On another occasion, when Colin was informed that a new genus, Ridsdalea, was going to be named after him, he wrote "... I was speechless, sat down in amazement and had a glass of wine to ward off any possible heart attack!"

Throughout his career Colin held strong views on where tropical botany, flora projects, and conservation research should go and he was not afraid to confront policy makers who did not agree. At the same time he was a very kind and helpful colleague and friend who will be sadly missed.

\section{Eponymy}

Ardisia ridsdalei C.M.Hu, Blumea 47, 3: 503. 2002. Myrsinaceae

Barringtonia ridsdalei Chantar., Kew Bull. 50, 4: 700. 1995. Lecythidaceae

Bungarimba ridsdalei K.M.Wong, Sandakania 15: 45. 2004. Rubiaceae

Diospyros ridsdalei Kosterm., Blumea 23, 2: 467. 1977. Ebenaceae

Dolicholobium ridsdalei M.E.Jansen, Blumea 29, 1: 303. 1983. Rubiaceae

Gynochthodes ridsdalei Razafim. \& B.Bremer, Adansonia 33, 2: 297. 2011. Rubiaceae

Ixora ridsdalei Mouly \& B.Bremer, Amer. J. Bot. 96, 3: 702. 2009. Rubiaceae

Lasianthus ridsdalei H.Zhu, Blumea 57, 1: 79. 2012. Rubiaceae

Melicope ridsdalei T.G.Hartley, Allertonia 8, 1: 128. 2001. Rutaceae

Myristica colinridsdalei W.J.de Wilde, Blumea 42, 1: 156. 1997. Myristicaceae

Planchonella ridsdalei (Vink) Swenson, Taxon 62, 4: 762. 2013. Sapotaceae

Pouteria ridsdalei Vink, Blumea 47, 1: 136. 2002. Sapotaceae

Ridsdalea J.T.Pereira \& K.M.Wong, Sandakania 21: 42. 2016. Rubiaceae

Syzygium ridsdalei Craven \& N.Snow, Harvard Pap. Bot. 15, 1: 131. 2010. Myrtaceae 


\section{BIBLIOGRAPHY}

1968

- Botanical results of the New Guineas Border Demarcation Expedition. Transactions of Papua \& New Guinea Scientific Society 9: 1-22.

1970

- The arborescent Naucleae of New Guinea and Solomon Islands (Rubiaceae). Gardens' Bulletin 25, 2: 247-281.

1972

- (with Van den Brink RB, Koek-Noorman J) Notes on New Guinea Rubiaceae. Versteegia and Maschalodesme. Blumea 20, 2: 339-350.

1973

- Numerical and taxonomic studies on the genus Uncaria Schreb. Thesis. University of Bristol. 313 pp., 59 plates.

1974

- A revision of the family Leeaceae. Blumea 22, 1: 57-100.

- Stipules, stipules, more stipules. Flora Malesiana Bulletin 27: 2207.

1975

- (with Phillipson JD, Hemingway SR) The chemotaxonomic significance of alkaloids in Naucleeae. Journal of Pharmacy and Pharmacology 26. Suppl.: 113-114.

- Notes on New Guinea Rubiaceae. Chaetostachydium. Blumea 22, 2: 267-269.

- Tree architecture, in field and herbarium. Flora Malesiana Bulletin 28, 1 : 2371-2374.

- (with Van den Brink Jr RB) A synopsis of the African and Madagascan Rubiaceae-Naucleeae. Blumea 22, 3: 541-553.

\section{6}

- A revision of the tribe Cephalantheae (Rubiaceae). Blumea 23, 1: 177-188.

- Leeaceae. Flora Malesiana Series 1, Spermatophyta 7: 755-782.

- Leeaceae. Identification lists of Malesian specimens 51: 917-937.

\section{8}

- (with Phillipson JD, Hemingway SR) Alkaloids of Uncaria. V. Their occurrence and chemotaxonomy. Lloydia 41: 503-570.

- The identity of Quiducia Gagnep. Blumea 24, 1: 42-42.

- A revision of Mitragyna and Uncaria (Rubiaceae). Blumea 24, 1: 43-100.

1979

- A revision of the tribe Naucleeae ss (Rubiaceae). Blumea 24, 2: 307-366.

- Jackiopsis, a new name for Jackia Wall. (Rubiaceea-Jackieae). Blumea 25, 1: 295-296.

- The taxonomic position of Dunnia (Rubiaceae). Blumea 24, 2: 367-368.

- Notes on New Guinea Rubiaceae: Rhadinopus. Blumea 25, 1: 297-300.

- The taxonomic position of Sulitia (Rubiaceae). Blumea 25, 1: 301-303.

1980

- The Rubiaceae in Hortus Malabaricus. In: Manilal KS (ed.), Botany and history of Hortus Malabaricus: 128-138. New Delhi etc., Oxford \& IBH Publ. Co.

- Leea asiatica, a new name for Nalugu Rheede. In: Manilal KS (ed.), Botany and history of Hortus Malabaricus: 189-190. New Delhi etc., Oxford \& IBH Publ. Co.

1981

- (with Geesink R, Leeuwenberg AJM, Veldkamp JF) Thonner's analytical key to the families of flowering plants. Pudoc/Leiden Univ. Press, $26+$ 231

\section{2}

- (with Phillipson JD, Hemingway SR) The chemotaxonomic significance of alkaloids in the Naucleeae s.I. (Rubiaceae). Journal of Natural Products 45, 2: 145-162.

- Spathichlamys - A remarkable Rubiacea. Blumea 28, 1: 143-144.

- Arevision of Badusa (Rubiaceae, Condamineeae, Portlandiinae). Blumea 28, 1: 145-150.

- (with Van Steenis CGGJ) Plants described by A. Gilli. Blumea 28, 1: 165-169. Rubiaceae, p. 169.
1983

- (with Jansen M) A revision of the genus Dolicholobium (Rubiaceae). Blumea 29, 1: 251-311.

1985

- (with Anderson LA, Keene AT, Phillipson JD) Hasskarl's Cinchona barks. 1. Historical review. Reinwardtia 10: 245-264.

- The genus Fagerlindia (Rubiaceae) in the Philippines. Blumea 31, 1: 239-244.

1988

- (with Siemondsma JS, Jansen PCM) Report Prosea mission to Thailand and the Philippines. Agric. Univ. Wageningen 1-18, append. I-XI.

1989

- (with Mandia EH) Archangelisia flava (L.) Merr. Plant Resources of South East Asia; A selection: 49-50.

- A revision of Neonauclea (Rubiaceae). Blumea 34, 1: 177-275.

1992

- (with Newbery DM, Campbell EJF, Lee YF, Still MJ) Primary lowland Dipterocarp forest at Danum Valley, Sabah, Malaysia - Structure, relative abundance and family composition. Philosophical Transactions of the Royal Society of London Series B-Biological Sciences 335(1275): 341-356.

- Uncaria gambir (Hunter) Roxb. Plant Resources of South-East Asia 3: $125-127$.

1995

- Manila Zoo Botanical Garden 2000: 1-28 + technical appendix 1-54. NMCP, The Hague.

1996

- A review of Aidia sl (Rubiaceae) in Southeast Asia and Malesia. Blumea 41, 1: 135-179.

- New taxa and combinations for the Rubiaceae of Sri Lanka. Blumea 41 2: $455-462$.

1998

- Rubiaceae. In: Dassanayake MD, Clayton WD (eds), A revised handbook to the Flora of Ceylon vol. XII: 309-320. Balkema Publishers, Rotterdam.

\section{9}

- (with Newbery DM, Kennedy DN, Petol GH, Madani L) Primary forest dynamics in lowland dipterocarp forest at Danum Valley, Sabah, Malaysia, and the role of the understorey. Philosophical Transactions of the Royal Society B-Biological Sciences 354(1391): 1763-1782.

2000

- (with Newbery DM, Kennedy DN, Petol GH, Madani L) Correction for Newbery et al., Primary forest dynamics in lowland dipterocarp forest at Danum Valley, Sabah, Malaysia, and the role of the understorey (vol B354, p. 1763, 1999). Philosophical Transactions of the Royal Society of London Series B-Biological Sciences 355(1404): 1865.

- (with MackA, Alonso L) Trees of the Wapoga River Area, Irian Jaya, Indonesia. A biological assessment of the Wapoga River Area of Northwestern Irian Jaya, Indonesia. RAP Bulletin of Biological Assessment 14: 34-36.

2002

- (with Mulyaningsih T) The Bornean genus Hypobathrum (Rubiaceae). An investigation of its characters and taxonomic status. Reinwardtia 12, 1: 95-116.

2003

- The Bornean genus Hypobathrum (Rubiaceae), an investigation of its characters and taxonomic status. Reinwardtia 12, 1: 95-116.

- (with Mulyaningsih T) An additional species of Villaria Rolfe (Rubiaceae) from the Philippines. Reinwardtia 12, 2: 195-197.

2004

- (with Arances JB, Amoroso V, Gruezo W, Visser L, Tan BC, Rufila LV, Galvezo JB, Opiso GS, Comilap R) Development of a participatory methodology for inventory and assessment of floral resources and their characterization in the montane forests of Mt. Malindang. The Biodiversity Research Programme for Development in Mindanao: Focus on Mt. Malindang and Environs, SEAMEO SEARCA, College, Laguna. PDM Press, Inc., Quezon City, Philippines. 
2005

- (with Bischoff W, Newbery DA, Lingenfelder M, Schnaeckel R, Petol GH, Madani L) Secondary succession and dipterocarp recruitment in Bornean rain forest after logging. Forest Ecology and Management 218(1-3): 174-192.

- (with White J, Usher C) Trees. DK Publishers, Eyewitness Companions series, 360 pp. Translated as: Bäume der Welt (2006).

\section{6}

- (with Grard P, Homsombath K, Keßler P, Khuon E, Le Bourgeois T, Prosperi M-J) OSWALD v. 1.0. A multimedia identification system of the major weeds of rice paddy fields of Cambodia and Lao PDR. http://agritrop. cirad.fr/580508/.

\section{8}

- Notes on Malesian Naucleeae. Reinwardtia 12, 4: 285-288.

- Thorny problems in the Rubiaceae: Benkara, Fagerlindia and Oxyceros. Reinwardtia 12, 4: 289-298.

- (with Svengsuksa B, Keßler P, Prosperi M-J, Grard P, Lamxay V, Edelin C) BIOTIK. Northern Annamites v 1.0. A multimedia identification system of tree species of the Northern Annamites, Lao PDR. http://www.biotik. org/downloads/NA_Setup.exe.
2011

- (with Newbery DM, Lingenfelder M, Poltz KF, Ong RC) Growth responses of understorey trees to drought perturbation in tropical rainforest in Borneo. Forest Ecology and Management 262, 12: 2095-2107.

2012

- (with Pereira JT) A synopsis of Rothmannia (Rubiaceae) in the Philippines with four new combinations and a new species. Sandakania 18: 15-32.

- (Zhu H, Roos MC) A taxonomic revision of the Malesian species of Lasianthus (Rubiaceae). Blumea 57, 1: 1-100.

2014

- (with Keene LAA) Hasskarl's Cinchona barks 1. Historical review. Reinwardtia 10, 2: 245-264.

2016

- (with Newbery DM) Neighbourhood abundance and small-tree survival in a lowland Bornean rainforest. Ecological Research 31, 3: 353-366. 